\title{
In Memory of Ashin Das Gupta and Charles Boxer
}

Recently Itinerario has lost two of its oldest and staunchest friends and subscribers. Ashin Das Gupta (1932) passed away in 1998 and just before this issue was due to go to press we were informed by Professor Dauril Alden that Charles Ralph Boxer (1903) had died at the great age of 96 .

Shortly after the Center for the History of European Expansion was established in 1974 we started publishing a bi-lingual Newsletter that was soon succeeded by Itinerario. All this took place some 25 years ago, when Ashin Das Gupta was in his fourties and Charles Ralph Boxer in his early seventies. By then they were already epic figures, each with his own impeccable style of writing. They both frequently corresponded with the then editors and looked in on us whenever they were in the neighborhood.

At the height of his distinguished career as a historian Ashin Das Gupta was working closely with Professor Dietmar Rothermund in Heidelberg and would show up at conferences there whenever he could. Passing through Holland he would without exception call upon the by then already retired archivist, Professor M.A.P. Meilink-Roelofsz. He admired her greatly, not only for her pioneering work, but also because it was she who had introduced him as a young scholar in the 1950s to the secrets of the VOC archives at the Algemeen Rijksarchief in The Hague. In the 1970s he was developing a completely new line of research focusing on the biography of an Indian merchant to describe the decline of Surat. For the first time new insights were offered into the personal histories of Asian actors in the marketplace, an achievement previously considered impossible. During these visits to The Hague, Professor Das Gupta always showed up at the 'loempia-lunch' every Wednesday in a Chinese restaurant near the archives which were then still situated in the old premises at Bleijenburg. With his owlish look and soft spoken humor he was a great inspiration to all the young researchers around the table as they listened to his wise words and elegantly phrased exposés. Sometime in the 1980 s we stopped seeing Profes'sor Das Gupta, although every now and then a fond message would arrive by letter, via a visiting student, or simply by way of a returning visitor from India. It was through his lifelong friend, Professor Peter Marshall, that we 
heard quite a long time ago that he was ailing. Both George Winius and I had long wanted to do an extensive interview for Itinerario with Das Gupta, we then quite suddenly realized that the chance had passed us by. By the time Dr Bhaswati Battacharya offered to do an interview with her teacher while visiting her relatives in Calcutta it was almost too late. Speaking had by then already become such a strain for Professor Das Gupta that the interview had to be a very short one. However brief it may have been, we are very happy to publish it together with the review by Ernst van Veen of the important collection of essays by close friends and collaborators which was intended to be a Festschrift but has instead become a memorial volume.

Another much more frequent visitor to Holland in the 1970s and 1980s was Professor Charles Boxer. Professor Boxer would visit the archives to check some dates and, of course, occasionally give those rousing, entertaining lectures for which he was so famous. But, frankly speaking, his main goal always was a visit to the book antiquarians Max and Nico Israel in Amsterdam with whom he was always trading manuscripts and books. Occasionally he would be accompanied by his formidable wife, Emily Hahn of China to me fame, renowned for her frequent articles in the New Yorker. On his travels Boxer always carried along some rare books or exotic items like a little bottle of pepper salvaged from a shipwreck. His craving for collecting indeed explains the personal style of his writings and in a certain sense will always set this formidable figure apart from his contemporaries as well as the generations of historians to come. Boxer basically wrote his books and articles on the basis of his own library and collection. He saw himself first as a collectionneur and secondly as a historian, a fact he confided to us, not without some irony. As I am sure that there will be many obituaries on the way, I shall not even try to. write anything of that kind. We should be very grateful that Dauril Alden, the author of The Making of an Enterprise, the Society of Jesus in Portugal, Its Empire, and Beyond, 1540-1750 (Stanford 1996), decided a few years ago to interrupt his research into the Jesuits in order to write the long awaited biography of this extraordinary figure. That book should be out any time now.

There is of course a nagging question which readers of Itinerario certainly want to get an answer to: why was Boxer never interviewed by Itinerario? The answer is that he actually was interviewed by us in the late 1970s. While Charles Boxer was not at all against publicity when it concerned his work, he simply abhorred speaking about himself and his intriguing career. George Winius and I switched on a tape recorder after a copious dinner and actually found him willing to talk about his life, the years with the army in Japan and Hong Kong, his twenty years at Queen's college in London, the rather brief spells as a professor at various universities in the US, his friendships with remarkable people like maritime historian Warnsinck, the pre-war Ambassador Van Pabst, the sinologist extraordinaire Van Gulik and countless Portuguese historians and so on. After we had edited 
the interview out and sent it to him for approval, we received a short note that he would prefer us to refrain from publishing it. Consequently this frank testimony never appeared. Fifteen years later Roelof van Gelder of NRC Handelsblad went to see Boxer at his home in Little Gaddesden (provided with a copy of our effort) and was able to make made a vastly better interview which was actually published. By then Boxer had given up most objections to talking about his past. It might be a good idea to publish Van Gelder's piece in English translation in one of Itinerario's forthcoming issues. Little Gaddesden with its treasures of manuscripts and rare editions turned over the years into something like un lieu de pelerinage for a crowd of young and no longer young admirers.

Leonard Blussé 